\title{
ОБЗОР ОСОБЕННОСТЕЙ АДМИНИСТРАТИВНОГО ПРАВА B НЕКОТОРЫХ СТРАНАХ
}

\author{
(c) 2021 Сатушиева Любовь Хабасовна
}

кандидат юридических наук, доцент кафедры конституционного и административного права Кабардино-Балкарский государственный университет имени Х. М. Бербекова, Россия, Нальчик

() 2021 Кастуева А. 0.

старший преподаватель кафедры трудового и предпринимательского права

Кабардино-Балкарский государственный университет имени Х. М. Бербекова, Россия, Нальчик

(C) 2021 Исаков А.P.

доцент кафедры конституционного и административного права

Кабардино-Балкарский государственный университет имени Х. М. Бербекова, Россия, Нальчик

\author{
(c) 2021 Зашезова Милана Анзоровна \\ студентка 4 курса юридического факультета \\ РУДН, Россия, Москва
}

В статье приводится краткий обзор особенностей административного права отдельных стран. Административное право в зарубежных странах возникло в Новое время. Формирование самостоятельного гражданского общества потребовало установления четких правовых рамок для всей государственно-управленческой деятельности, осуществления ее на началах законности. Вначале на европейском континенте (XIX в.), а позднее в Англии и США (XX в.) возникает комплекс правовых норм, регулирующих организацию исполнительной власти, правовое положение ее органов, их отношения с частными лицами. Наиболее интересны для ознакомления модели административноправового регулирования Франции и Великобритании, которые являются типичными для систем континентального и англосаксонского права. Изучение опыта применения административного права различных стран дает возможность перенять его в систему национального права, перейти к общим нормам административного права. Теоретическую основу данного вопроса составляют труды зарубежных правоведов, нормативные документы стран. Предметом публикации выступают особенности развития административного права в некоторых странах.

Ключевые слова: административное право, административное право зарубежных стран

Административное право (или нормативное право) - это совокупность правовых норм, возникающих в результате деятельности административных органов правительства, которая отличается от частного права, возникающего в результате деятельности частных лиц, корпораций и неправительственных организаций. Действия государственных органов могут включать в себя нормотворчество, вынесение судебных решений или обеспечение выполнения определенной нормативной повестки дня. Административное право считается отраслью публичного права. Как совокупность правовых норм, административное право касается принятия решений административными единицами правительства (включая суды, советы и комиссии), которые являются частью национальной системы регулирования в таких областях, как между- народная торговля, производство, окружающая среда, налогообложение и т.д. радиовещание, иммиграция и транспорт [1].

По мере того как правительства росли в размерах и мощи, возникла необходимость в разработке системы законов, регулирующих управление населением, чтобы поддерживать порядок, обеспечивать эффективность, сохранять экономику и поддерживать контроль над растущей бюрократией. По мнению зарубежных юристов в качестве основы, использующей конституционные, судебные и политические полномочия, административное право значительно расширилось в течение двадцатого века, поскольку законодательные органы по всему миру создали больше правительственных агентств для регулирования все более сложных социальных, экономических и политических сфер человеческого 
взаимодействия и для улучшения развитие отдельных лиц, семей и сообществ [1].

Административное право в Соединенных Штатах часто связано с так называемыми «независимыми агентствами», такими как Федеральная торговая комиссия («FTC»), или исходит от них. Штаб-квартира FTC находится в Вашингтоне, округ Колумбия.

В административном праве нормотворчество относится к процессу, который исполнительные органы используют для создания или опубликования нормативных актов. Как правило, законодательные органы сначала устанавливают широкие политические полномочия, принимая законы, а затем агентства создают более подробные правила посредством нормотворчества.

Привлекая подробные научные знания к политике, процесс нормотворчества способствовал успеху некоторых из наиболее заметных государственных достижений двадцатого века. Например, научно обоснованные правила имеют решающее значение для современных программ защиты окружающей среды, безопасности пищевых продуктов и безопасности на рабочем месте [1]. Однако взрывной рост нормативных требований вызвал критику в отношении того, что процесс нормотворчества снижает прозрачность и подотчетность демократического правительства.

Вынесение судебного решения - это юридический процесс, с помощью которого арбитр или судья рассматривают доказательства и аргументацию, включая юридические доводы, изложенные противоборствующими сторонами или сторонами в судебном процессе, для принятия решения, определяющего права и обязанности участвующих сторон.

В судебном порядке разрешаются три типа споров:

1. Споры между частными лицами, например, физическими или юридическими лицами.

2. Споры между частными лицами и государственными должностными лицами.

3. Споры между должностными лицами или государственными органами.

Вступление в силу (также называемое исполнением или введением в действие) относится к дате и процессу, в результате которого законодательство или его часть вступают в законную силу. Важно отметить, что процесс, посредством которого законопроект становится законом, пол- ностью отличается от процесса вступления закона в силу. Законопроект, даже если он принят законодателями, не является законом, не может иметь никакой силы. Конечно, может случиться так, что закон страны определяет, что после принятия законодателями законопроект без дальнейших церемоний становится законом. Однако чаще всего процесс, посредством которого законопроект становится законом, четко прописан в общем конституционном или административном законодательстве. Этот процесс варьируется от страны к стране и от политической системы к политической системе. Как правило, процесс, посредством которого Билл становится закон будет включать в себя, что законопроект будет подписан главой государства, и что оно будет опубликовано в официальном бюллетене, так что люди знают, что закон существует и в целом высвобождает его в общественном достоянии.

Вообще говоря, большинство стран, которые следуют принципам общего права, разработали процедуры судебного надзора, которые ограничивают возможность пересмотра решений, принимаемых органами административного права. Часто эти процедуры сочетаются с законодательством или другими доктринами общего права, которые устанавливают стандарты для надлежащего нормотворчества.

Административное право может также применяться к пересмотру решений так называемых квазигосударственных органов, таких как некоммерческие корпорации, дисциплинарные советы и другие органы, принимающие решения, которые влияют на законные права членов определенной группы или юридического лица. Хотя органы, принимающие административные решения, часто контролируются более крупными государственными единицами, их решения могут быть пересмотрены судом общей юрисдикции в соответствии с некоторым принципом судебного надзора на основе надлежащей правовой процедуры (США) или фундаментального правосудия (Канада). Следует отметить, что судебный пересмотр административного решения отличается от апелляции. При пересмотре решения суд будет рассматривать только метод, которым было принято решение, тогда как при рассмотрении апелляции правильность самого решения будет поставлена под сомнение. Это различие жизненно важно для понимания административного права в странах общего права.

Объем судебного надзора может быть огра- 
ничен определенными вопросами справедливости или того, является ли административное действие ultra vires. С точки зрения действий ultra vires в широком смысле, апелляционный суд может отменить административное решение, если оно является явно необоснованным (в соответствии с законодательством Канады), необоснованным по Веднсбери (в соответствии с законодательством Великобритании) или произвольным и капризным (в соответствии с Законом об административных процедурах США и Закон штата Нью-Йорк). Административное право, установленное Верховным судом Индии, также признало еще два основания для судебного пересмотра, которые были признаны, но не применялись английскими судами.

Полномочия по пересмотру административных решений обычно устанавливаются статутом, но изначально были разработаны на основе королевских прерогативных предписаний английского права, таких как судебный приказ о мандамусе и судебный приказ о сертификации. В некоторых юрисдикциях общего права, таких как Индия или Пакистан, право передавать такие судебные приказы является правом, гарантированным Конституцией [1]. Это право считается основополагающим для права судебного надзора и аспектом независимой судебной системы.

Австралия

Административное право Австралии определяет объем полномочий и ответственности административных органов правительства Австралии. Это система общего права с весьма значительным наложением законодательных норм, в котором акцент сместился на суды общего характера и кодифицированный судебный надзор. Австралия обладает хорошо развитой системой омбудсменов и законами о свободе информации, на которые повлияли сопоставимые изменения за рубежом. Его требования к уведомлениям и комментариям для принятия делегированного законодательства имеют параллели с Соединенными Штатами. Заимствования Австралии из-за границы все еще в значительной степени формируются ее эволюцией в рамках системы парламентской демократии, которая в целом следует вестминстерской системе ответственности и подотчетности.

Развитие административного права за последние три десятилетия было охарактеризовано как «тихая революция» [2]. На применение административного законодательства в настоящее время влияет сдвиг в сторону дерегулирования и приватизации.

Канада

Канадское административное право - это свод законов Канады, регулирующий действия и операции правительств и правительственных агентств [2]. То есть закон касается того, каким образом суды могут пересматривать решения лиц, принимающих административные решения (ADM), таких как правление, трибунал, комиссия, агентство или министр. Свод законов касается в первую очередь вопросов проверки по существу (определение и применение стандарта проверки) и вопросов процессуальной справедливости (обеспечение прав на участие).

Индия

Конституция Индии - самая длинная письменная конституция страны, содержащая 444 статьи, 12 приложений, многочисленные поправки и 117369 слов [1]. Индийский закон относится к системе права, которая действует в Индии. Он в значительной степени основан на английском общем праве из-за длительного периода британского колониального влияния в период британского владычества. Большая часть современного индийского законодательства демонстрирует значительное влияние Европы и Америки [1]. Различные законы и постановления, впервые введенные британцами, все еще действуют в измененной форме сегодня. Во время разработки Конституции Индии законы Ирландии, США, Великобритании и Франции были синтезированы, чтобы получить усовершенствованный набор индийских законов в его нынешнем виде. Индийские законы также соответствуют требованиям ООН. Некоторые законы международной торговли, например законы об интеллектуальной собственности, также соблюдаются в Индии.

Индийское гражданское право сложное, и каждая религия имеет свои собственные законы, которых они придерживаются. В большинстве штатов регистрация браков и разводов не является обязательной. Есть отдельные законы, регулирующие индуистов, мусульман, христиан, сикхов и последователей других религий. Исключением из этого правила можно назвать штат Гоа, где действует единый португальский гражданский кодекс, в котором для всех религий существует общий закон в отношении браков, разводов и усыновления. В отличие от большин- 
ства юрисдикций общего права, в большинстве юрисдикций гражданского права есть специализированные суды или секции для рассмотрения административных дел, которые, как правило, будут применять процессуальные правила, специально разработанные для таких дел и отличные от тех, которые применяются в частноправовых разбирательствах, например как контрактные или деликтные иски.

Франция

Основа французского гражданского права была сформирована из Гражданского кодекса или Кодекса Наполеона, который включал в себя некоторые свободы, полученные народом в результате Французской революции. Более того, Наполеон ввел кодексы административного права, которые способствовали созданию эффективных правительств и установлению общественного порядка. Большинство исков к национальным или местным органам власти рассматриваются административными судами, которые используют Государственный совет как суд последней инстанции. Этот суд действует как орган французского национального правительства и является верховным судом административного правосудия, а также оказывает юридические консультации исполнительной власти.

Административное право регулирует отношения между государством (в его различных проявлениях) и частными гражданами или организациями. Нормы административного права изложены, в частности, в Административном кодексе или Административном кодексе, хотя, как и в случае с уголовным правом, существует также большое количество законодательных и нормативных текстов, которые являются самостоятельными, например, тексты, регулирующие статус и полномочия. отраслевых регуляторов (большинство из которых имеют статус autorité Administrative Independante или AAI) [1].

Административное право во Франции можно разделить на две основные категории: общее административное право и отраслевое административное право.

Германия

В Германии высшим административным судом по большинству вопросов является федеральный административный суд Bundesverwaltungsgericht.

Существуют федеральные суды со специальной юрисдикцией в области права социального обеспечения (Bundessozialgericht) и налогового права (Bundesfinanzhof).
Публичное право (Öffentliches Recht) регулирует отношения между гражданином или частным лицом и официальным лицом или между двумя официальными лицами. Например, закон, определяющий налоги, всегда является частью публичного права, как и отношения между публичным органом Федерации (Бунд) и публичным органом государства (земли). Публичное право обычно основывается на так называемом Über-Unterordnungs-Verhältnis («отношения превосходства и неполноценности»). Это означает, что государственный орган может определять, что следует делать, без согласия гражданина. (Так, например, если орган власти приказывает гражданину платить налоги, гражданин должен платить, даже без соглашения.) В свою очередь, орган власти должен соблюдать закон и может распоряжаться только в том случае, если он уполномочен законом.

\section{Нидерланды}

В Нидерландах положения административного права обычно содержатся в отдельных законах. Однако существует единый Закон об общем административном праве (Algemene Wet Bestuursrecht или AWB), который применяется как к принятию административных решений, так и к судебному пересмотру этих решений в судах. На основании AWB граждане могут опротестовать решение (besluit), принятое государственным органом (bestuursorgaan) в рамках администрации, и подать заявление о судебном пересмотре в суде в случае его неудачи. В отличие от Франции или Германии, в Нидерландах нет специальных административных судов первой инстанции, но в обычных судах есть административный «сектор», который специализируется на рассмотрении административных апелляций. Однако апелляционные суды по административным делам являются специализированными в зависимости от дела, но большинство административных апелляций попадают в Судебную секцию Государственного совета (штат Раад ван). В дополнение к описанной выше системе существует еще одна часть административного права, которая называется administratief beroep (административное обжалование). Эта процедура доступна только в том случае, если закон, на котором основано первичное решение, прямо предусматривает ее и предусматривает обжалование в административном органе более высокого уровня. Если доступна административная апелляция, апелляция в судебную систему невозможна. 


\section{Китай}

Китайское право - одна из старейших правовых традиций в мире. На протяжении большей части истории Китая он основывался на конфуцианской философии социального контроля через нравственное воспитание, а также на акценте легистов на кодифицированном праве и уголовных санкциях. В отличие от многих других крупных цивилизаций, где писанный закон почитался и часто приписывался божественному происхождению, закон в Китае рассматривался с чисто светской точки зрения, и его первоначальное появление было встречено многими враждебно как свидетельство серьезного морального упадка, нарушения человече- ского права [1]. Осведомленность простых людей об этических нормах и их принятие были сформированы в гораздо большей степени повсеместным влиянием обычаев и использования собственности, а также насаждением моральных заповедей, чем какой-либо официально принятой системой права. Что касается китайской веры в космический порядок, считалось, что правильное поведение - это поведение, созвучное имманентному порядку, который устанавливает границы для соответствующих реакций. Фа определяет эти границы, в то время как син определяет потенциальные затраты для человека за их превышение и налагает штрафы за эти действия.

\section{Библиографический список}

1. https://www.newworldencyclopedia.org/entry/Administrative_law

2. Кервин, К. М. Нормотворчество: как государственные органы пишут законы и вырабатывают политику. Вашингтон, округ Колумбия: CQ Press, 1994. ISBN 087187993X

3. Пирс, Ричард Дж. И Кеннет Калп Дэвис. Трактат об административном праве. Нью-Йорк: Закон и бизнес Аспена, 2002. ISBN 0735521506

4. Уэйд, Уильям и сэр Кристофер Форсайт. Административный закон. Оксфорд, Великобритания: Охford University Press, 2000. ISBN 0585381607

5. https://lawbook.online/administrativnoe-pravo-rossii-kniga/administrativnoe-pravo-zarubejnyih-20627.html 